\title{
PHYTOEXTRACTION ASSESSMENT OF GREEN AMARANTH (Amaranthus viridis Linn.) GROWN ON SOIL AMENDED WITH SEWAGE SLUDGE
}

\author{
Towolawi ${ }^{1}$, A. T., Arowolo ${ }^{1}$, T. A., Bada ${ }^{1}$, B. S., Badejo ${ }^{2}$, A. A. and Taiwo, A. M. ${ }^{1}$ \\ ${ }^{1}$ Department of Environmental Management and Toxicology, Federal University of Agriculture, Abeokuta, Ogun State, \\ Nigeria \\ ${ }^{2}$ Department of Civil Engineering, Federal University of Agriculture, Abeokuta, Ogun State, Nigeria. \\ Corresponding author: taofiktowolawi@yahoo.com \\ (Received: 17th October, 2016; Accepted: 27th June, 2017)
}

\begin{abstract}
Disposal of sewage sludge is the major challenge facing wastewater treatment facilities. Several reports claimed that land application is the best option to manage sludge disposal. However, there is perception that sludge contains heavy metals that are potentially harmful to the living organisms. Thus, the study assessed heavy metals uptake of Amaranthus viridis grown on soil amended with sludge sourced from three wastewater treatment facilities. The vegetable was chosen because it is mostly planted by the farmers who could replace NPK fertiliser which is expensive with readily and freely available sludge from the facilities in Lagos State. The plant shoot harvested at 42 days and the amended soil after harvest were analysed for 5 selected heavy metals $(\mathrm{Cu}, \mathrm{Zn}, \mathrm{Cd}, \mathrm{Cr}$ and $\mathrm{Pb}$ ) using standard methods. To know which portions of the vegetable the metals were accumulated, transfer factor, bioconcentration factor and translocation index were computed for phytoextraction test. The results showed that the transfer factor of $\mathrm{Zn}>1$ but of $\mathrm{Cu}<1$. Both bioconcentration factor and translocation index were $<100$. The $\mathrm{Cd}, \mathrm{Cr}$ and $\mathrm{Pb}$ were below the machine detection limits. The study observed that the levels of heavy metals absorbed by the vegetable were insignificant when compared to the amount remaining in the soil.
\end{abstract}

Key Words: Sewage sludge, Green amaranth, Phytoextraction, Heavy metals.

\section{INTRODUCTION}

Phytoextraction is the uptake of pollutants by plants in soil or on water contaminated with heavy metals, metalloids and radionuclides (Usman et al., 2013). Efficacy of heavy metals extraction by plants varies with types of metals, wastewater sources and compositions (Khalid et al., 2012). Persistence, bioaccumulation and biomagnifications of heavy metals influence their ecotoxicity in high doses beyond threshold (Abel et al., 2006) and harmful to plants when accumulated. Increase in sewage generation has triggered its being thought as amendment on agricultural land and a way to recycle sludge and nutrient (Gupta et al., 2008). Though heavy metals in the sludge may adversely affect human, plant or animal life if present above threshold, their potential to amend the soil with plant nutrients, soil structure and other characteristics cannot be doubted (Antonious and Snyder, 2007). Presence of substantial amounts of nitrogen and phosphorus in sewage creates an opportunity for its re-use in agriculture and reclamation in preference to disposal (Khalid et al., 2012). Farmers with limited resource prefer organic fertilizers to chemical fertilizers in order to abate cost of production with respect to high cost of energy and fertilizers as well as soil degradation and erosion in relation to intensive farming systems (Antonious, 2003).

Studies on vegetables grown in soil amended with municipal solid waste compost in tropical countries had been carried out (Gupta et al., 2008). Amaranths, vegetable species, germinate better on fertile and well-drained alkaline soils $(\mathrm{pH}>6)$ with a loose structure. Its mineral uptake is very high and can be harvested 4-5 weeks after planting. Amaranths thrive on soils rich in nitrogen, though high levels of nitrogen will delay the onset of flowering thereby prolonging their vegetative growth. Locally known as 'tete' (Yoruba), 'green,' (Igbo) or 'aleho' (Hausa) in Nigeria. Amaranthus has excellent nutritional value because of its high content of essential micronutrients such as $\beta$ carotene, iron, calcium, vitamin $\mathrm{C}$ and folic acid (Priya et al., 2007). Phytoextraction may be monitored using different indices which include the transfer factor and daily intake of metals (Kumar et al., 2009), bioconcentration factor (Ghafoori et al., 2011) and translocation index (Mishra et al., 2008). Thus, the study used sludge as 
soil amendment to grow Amaranthus viridis which is commonly grown in some farm settlements in Lagos State (Southwest, Nigeria) and assessed the plant for heavy metals uptake.

\section{MATERIALS AND METHODS}

Sewage sludge, soil and Amaranthus viridis seed samples collection

Samples of sewage sludge were sourced from Lagos State wastewater treatment facilities; Abesan estate Iyana-ipaja, Oke-Afa estate Isolo and Ikeja. Soil at the depth of $0-15 \mathrm{~cm}$ was sampled from the Teaching and Research Farm of Federal University of Agriculture, Abeokuta. Seed of Amaranthus viridis was sourced from National Horticultural Institute, Ibadan, Oyo State.

\section{Sample preparation and sewage sludge application}

Sample preparation and sludge application were carried out according to Bada et al. (2014). Samples of sludge and soil were air-dried for fourteen and three days respectively after which they were sieved using a $2 \mathrm{~mm}$ mesh for homogeneity. Thirty-six bottom perforated 7-litre plastic pots were filled with $5 \mathrm{~kg}$ of the soil sample. The sludge samples were used in this study as soil amendment in measured quantity according to the nitrogen requirement $\left(67.5 \mathrm{~kg} \mathrm{~N} \mathrm{ha}{ }^{-1}\right)$. Each sludge sample from Abesan, Ikeja and Oke-Afa at 67.5, 87.5 and $107.5 \mathrm{~kg} \mathrm{~N} \mathrm{ha}{ }^{-1}$ was used to amend each pot of $5 \mathrm{~kg}$ of the soil sample in three replicates, making 27 pots. Other pots of $5 \mathrm{~kg}$ soil samples were amended with NPK and imported organic fertilizer (Pupuk) at $67.5 \mathrm{~kg} \mathrm{~N} \mathrm{ha}{ }^{-1}$ in three replicates, making 6 pots. No-amended $5 \mathrm{~kg}$ pot in three replicates was also set up as control. All the 36 experimental pots were arranged in completely randomized design in the screen house of Federal University of Agriculture, Abeokuta, Nigeria. The pots were watered to field capacity and left for 21 days to mineralise. The drained leachate was returned into each pot to avoid nutrients loss.

\section{Laboratory analysis}

Soil (before and after harvest) and the harvested plants were analysed for accumulation of 5 selected heavy metals ( $\mathrm{Cu}, \mathrm{Zn}, \mathrm{Cd}, \mathrm{Cr}$ and $\mathrm{Pb}$ ). The harvested plant at 42 days was washed with distilled water, partitioned into root and shoot, and pulverized with pre-cleaned mortar and pestle. According to the method of Nurunnahar et al. (2012) digestion was done with nitric, sulphuric and perchloric acids in ratio 5:1:2 and the digested samples were analysed using Atomic Absorption Spectrometer (Buck Scientific, Model 210VGP, CT, USA).

\section{Phytoextraction test}

(1) Transfer factor (TF), the ratio of metals transport from soil to the test plant was calculated according the method of Kumar et al. (2009), as:

$$
\mathrm{TF}=\text { Whole plant } / \mathrm{TC}
$$

Whole plant (shoot + roots) metals concentration, while TC is soil metals concentration $(\mathrm{mg} / \mathrm{kg})$.

(2) Bioconcentration factor (BCF), the plant ability to accumulate metals from soil to the root was calculated according to Ghafoori et al. (2011), as:

$$
\mathrm{BCF}=\underset{\text { Concentration })) \times 100}{((\text { Root Concentration }) /(\text { Soil }}
$$

(3) Translocation index (TI), the species ability in metals translocation from root to shoot was calculated according to the method of Mishra et al. (2008), as:

$$
\begin{aligned}
\text { TI }(\%)= & ((\text { Shoot Metal Concentration }) /(\text { Root } \\
& \text { Metal Concentration })) \times 100
\end{aligned}
$$

\section{Statistical analyses}

The data collected were subjected to descriptive (mean and standard deviation), inferential (ANOVA and Duncan's Multiple Range Test) statistics.

\section{RESULTS AND DISCUSSION}

\section{Results of the soil and sewage sludge samples analyses}

From table 1, the results of analysis of heavy metals in soil with pH:- $7.78 \pm 1.99$ and sludge samples before amending and planting indicated the following values: $\mathrm{Zn}:-13.10 \pm 0.15 \mathrm{mg} \mathrm{kg}^{-1}$ and $\mathrm{Cu}:-6.00 \pm 0.20 \mathrm{mg} \mathrm{kg}^{-1}$ while $\mathrm{Cd}, \mathrm{Cr}$ and $\mathrm{Pb}$ in soil sample were below the detection limits and the soil standards for sludge land application. Values of the selected heavy metals determined in the soil in this study were lower than the values ( $\mathrm{Zn}$ :- 113.44 \pm 5.43, Cu:- $18.96 \pm 1.22$, Cd:- $0.57 \pm 0.22$, Pb:$12.85 \pm 1.11$ and Cr:- $29.07 \pm 2.33 \mathrm{mg} \mathrm{kg}^{-1}$ ) 
detected by Wang et al. (2008) which they compared with China State Environmental Protection Agency soil limits (Zn:- 300, Cu:- 100, Cd:- 0.6, Pb:- 350 and Cr:- $\left.250 \mathrm{mg} \mathrm{kg}^{-1}\right)$. The $\mathrm{pH}$ of the sludge samples ranged $(p<0.05)$ from $6.40 \pm$ 0.10 to $7.16 \pm 0.53$. The values of heavy metals $\left(\mathrm{mg} \mathrm{kg}^{-1}\right)$ in the sludge samples ranged $(\mathrm{p}<0.05)$ from Cd:- $0.01 \pm 0.01$ to $0.03 \pm 0.01$, Cu:- $5.80 \pm$ 0.40 to $7.40 \pm 0.30, \mathrm{Zn}:-6.78 \pm 0.68$ to $10.23 \pm$ 0.16. Chromium and $\mathrm{Pb}$ values were below the detection limits of the machine. Values of the selected heavy metals determined in the sludge in this study were lower than the values ( $\mathrm{Zn}$ :- 1872.23 $\pm 22.71, \mathrm{Cu}:-105.08 \pm 4.57, \mathrm{Cd}:-5.06 \pm 0.65, \mathrm{~Pb}:-$ $41.19 \pm 4.78$ and Cr:- $48.85 \pm 5.22 \mathrm{mg} \mathrm{kg}^{-1}$ ) detected by Wang et al. (2008) which were compared with China State EPA soil limits (Zn:3000, Cu:- 1500, Cd:- 0.6, Pb:- 1000 and Cr:- 1200 $\left.\mathrm{mg} \mathrm{kg}^{-1}\right)$. If heavy metals concentrations in sludge sample are lower than the allowable limits (Zn:1400, Cu:- 1500, Ni:- 420, Cd:- 39, Pb:- 300, Cr:1200, Mo:- $75 \mathrm{mg} \mathrm{kg}^{-1}$ ), such sludge sample would be beneficial to agricultural land application (Antonious et al., 2011).

Table 1: Heavy metals contents of the samples before planting

\begin{tabular}{lllll}
\hline Parameters & Soil & SSA & SSI & SSO \\
\hline $\mathrm{pH}$ & $7.78 \pm 1.99$ & $6.46 \pm 0.20^{\mathrm{a}}$ & $6.40 \pm 0.10^{\mathrm{a}}$ & $7.16 \pm 0.53^{\mathrm{b}}$ \\
Organic carbon $(\%)$ & $35.91 \pm 1.36$ & $22.34 \pm 1.24^{\mathrm{a}}$ & $33.52 \pm 0.30^{\mathrm{c}}$ & $26.34 \pm 0.26^{\mathrm{b}}$ \\
$\mathrm{Cd}(\mathrm{mg} / \mathrm{kg})$ & $<\mathrm{DL}$ & $0.03 \pm 0.01^{\mathrm{b}}$ & $0.02 \pm 0.01^{\mathrm{a}}$ & $0.01 \pm 0.00^{\mathrm{a}}$ \\
$\mathrm{Cr}(\mathrm{mg} / \mathrm{kg})$ & $<\mathrm{DL}$ & $<\mathrm{DL}$ & $<\mathrm{DL}$ & $<\mathrm{DL}$ \\
$\mathrm{Pb}(\mathrm{mg} / \mathrm{kg})$ & $<\mathrm{DL}$ & $<\mathrm{DL}$ & $<\mathrm{DL}$ & $<\mathrm{DL}$ \\
$\mathrm{Cu}(\mathrm{mg} / \mathrm{kg})$ & $6.00 \pm 0.20$ & $7.40 \pm 0.30^{\mathrm{b}}$ & $5.80 \pm 0.40^{\mathrm{a}}$ & $7.30 \pm 0.26^{\mathrm{b}}$ \\
$\mathrm{Zn}(\mathrm{mg} / \mathrm{kg})$ & $13.10 \pm 0.15$ & $10.23 \pm 0.16^{\mathrm{c}}$ & $6.78 \pm 0.68^{\mathrm{a}}$ & $8.14 \pm 0.07^{\mathrm{b}}$ \\
\hline
\end{tabular}

SS $=$ Sewage Sludge, SSA = Abesan, SSI = Ikeja, $\mathrm{SSO}=$ Oke-afa,$<\mathrm{DL}=$ Below detection limit

Amaranthus viridis transfer factor (whole plant to soil ratio)

Plant development relies on nutrients cycle and this enhances trace elements from soil to plant. Absorption of heavy metals from soil to plant is monitored with transfer factor (Table 2). No transfer factor was computed for $\mathrm{Cr}$ and $\mathrm{Pb}$ because their concentrations were below the detection limits. They might have been strongly adhered to the soil matrix (Oros, 2001). There was transfer of available essential elements $(\mathrm{Cu}$ and $\mathrm{Zn}$ ) from amended soil to $A$. viridis. The transfer factor for $\mathrm{Cu}$ ranged from $0.01 \pm 0.00$ in $107.5 \mathrm{~kg}$ Abesan sludge to $0.04 \pm 0.01$ in $67.5 \mathrm{~kg}$ Oke-afa sludge with no significant $(p>0.05)$ difference. The transfer factor for $\mathrm{Zn}$ ranged from $0.55 \pm$ 0.03 in $87.5 \mathrm{~kg}$ Abesan sludge to $2.20 \pm 0.23$ in $67.5 \mathrm{~kg}$ Oke-afa sludge with high significant $(\mathrm{p}<$ $0.05)$ differences. The amended soil pot with 67.5 $\mathrm{kg}$ Oke-afa sludge influenced highest transfer factor for $\mathrm{Cu}$ and $\mathrm{Zn}$. Transfer factors of $\mathrm{Zn}$ were greater than 1 and that meant $\mathrm{Zn}$ was more absorbed to $A$. viridis parts from soil in all treatments except in $87.5 \mathrm{~kg}$ Abesan sludge. This corroborated the study of Gupta et al. (2008) who observed that the transfer factor of metals $(\mathrm{Mn}$, $\mathrm{Zn}, \mathrm{Cu}$ and $\mathrm{Cd}$ ) detected to be $<1$ in tomato plants suggested lower metals extraction from soil. The low transfer factor of $\mathrm{Cu}$ might be as a result of its restriction by phytochelation (inherent restrictive mechanism) within the plant body (Gupta et al., 2008). However, the ranges of transfer factor values (Cu:- 0.01 to 0.04 and $\mathrm{Zn:-}$ 0.55 to $\left.2.20 \mathrm{mg} \mathrm{kg}^{-1}\right)$ at 42 days of harvest in this study were lower than the values (Cu:- 2.80 to 4.20 and $\mathrm{Zn}:-2.90$ to $4.40 \mathrm{mg} \mathrm{kg}^{-1}$ ) detected by Satpathy and Reddy (2013) at 45 days of harvest of Indian mustard. The ranges of transfer factor values in this study were lower than $\mathrm{Cu}: 0.09$ to $0.21 \mathrm{mg} \mathrm{kg}^{-1}$ but greater than Zn: 0.21 to $0.34 \mathrm{mg} \mathrm{kg}^{-1}$ that Wang et al. (2008) detected at 15 days of harvest of Chinese cabbage. Low level of $\mathrm{Pb}$ could have enhanced $\mathrm{Cu}$ and $\mathrm{Zn}$ but reduced $\mathrm{Cd}$ absorption. This corroborated the views of Kabata-Pendias and Pendias (1999) that high level of Pb decreased absorption of $\mathrm{Cu}$ and $\mathrm{Zn}$ but increased $\mathrm{Cd}$ absorption. 
Table 2: Amaranthus viridis transfer factor

\begin{tabular}{lll}
\hline $\begin{array}{l}\text { Amended Quantity } \\
\left.(\mathrm{kg} \mathrm{N} \mathrm{ha})^{-1}\right)\end{array}$ & $\mathrm{Cu}$ & $\mathrm{Zn}$ \\
\hline 67.5 SSA & $0.02 \pm 0.00^{\mathrm{ab}}$ & $1.46 \pm 0.07^{\mathrm{bcd}}$ \\
87.5 SSA & $0.01 \pm 0.00^{\mathrm{ab}}$ & $0.55 \pm 0.03^{\mathrm{a}}$ \\
107.5 SSA & $0.01 \pm 0.00^{\mathrm{a}}$ & $1.32 \pm 0.06^{\mathrm{bc}}$ \\
67.5 SSI & $0.02 \pm 0.01^{\mathrm{bcd}}$ & $1.73 \pm 0.09^{\mathrm{e}}$ \\
87.5 SSI & $0.03 \pm 0.01^{\mathrm{d}}$ & $2.16 \pm 0.29^{\mathrm{f}}$ \\
107.5 SSI & $0.02 \pm 0.00^{\mathrm{abc}}$ & $1.57 \pm 0.11^{\mathrm{cd}}$ \\
67.5 SSO & $0.04 \pm 0.01^{\mathrm{e}}$ & $2.20 \pm 0.23^{\mathrm{f}}$ \\
87.5 SSO & $0.02 \pm 0.00^{\mathrm{abc}}$ & $1.67 \pm 0.39^{\mathrm{d}}$ \\
107.5 SSO & $0.02 \pm 0.00^{\mathrm{abc}}$ & $1.18 \pm 0.03^{\mathrm{b}}$ \\
67.5 NPK & $0.01 \pm 0.00^{\mathrm{a}}$ & $1.56 \pm 0.11^{\mathrm{cd}}$ \\
Control & $0.01 \pm 0.00^{\mathrm{ab}}$ & $1.59 \pm 0.01^{\mathrm{cd}}$ \\
67.5 Pupuk & $0.02 \pm 0.00^{\mathrm{cd}}$ & $2.01 \pm 0.14^{\mathrm{ef}}$ \\
\hline
\end{tabular}

Superscripts with the same letters down the column are not significantly $(\mathrm{p}<0.05)$ different. SS = Sewage Sludge, SSA = Abesan, SSI = Ikeja, SSO = Oke-afa

Amaranthus viridis bioconcentration factor (root to soil ratio in \%)

Bioconcentration factor is the ratio of metal concentration in root to soil in percentage (Ghafoori et al., 2011). The $\mathrm{Cu}$ bioconcentration factor ranged from $0.52 \pm 0.15 \%$ in $107.5 \mathrm{~kg}$ Abesan sludge to $1.79 \pm 0.23 \%$ in $67.5 \mathrm{~kg}$ Oke-afa sludge with significant $(\mathrm{p}>0.05)$ difference (Table 3). The bioconcentration factor for $\mathrm{Zn}$ ranged from $17.22 \pm 0.11 \%$ in $87.5 \mathrm{~kg}$ Abesan sludge to $83.89 \pm 10.57 \%$ in $107.5 \mathrm{~kg}$ Ikeja sludge with high significant $(p>0.05)$ difference. This followed the assertion of Kamran et al. (2013) that plants grown in the $\mathrm{Zn}$ - and $\mathrm{Cu}$ polluted soils bioaccumulate them abundantly in the roots. The value of bioconcentration factor $<100$ indicated that level of Cd up taken by the test plant was lower than the Cd level in the soil (Yadav et al., 2013).

\section{Amaranthus viridis translocation index (shoot to root ratio in \%)}

Translocation index is the ratio of metal concentration in shoot to the root in percentage (Mishra et al., 2008) and implied heavy metals absorption across different plant (from roots to aerial) parts (Satpathy and Reddy, 2013). The value $(\%)$ of translocation index for $\mathrm{Cu}$ ranged from $43.77 \pm 3.56$ in $67.5 \mathrm{~kg}$ Pupuk fertilizer to $56.37 \pm$ 4.18 in $67.5 \mathrm{~kg}$ Oke-afa sludge with no significant
( $p>0.05)$ difference (Table 4). The value (\%) of translocation index for $\mathrm{Zn}$ ranged from $46.84 \pm$ 3.44 in $107.5 \mathrm{~kg}$ Ikeja sludge to $70.17 \pm 1.00$ in 67.5 $\mathrm{kg}$ Abesan sludge with high significant $(\mathrm{p}<0.05)$ difference. The values $(\%)$ of translocation index for $\mathrm{Cu}$ :- 43.77 to 56.37 and $\mathrm{Zn}$ :- 46.84 to 70.17 in this study at 42 days of harvest were lower than the values detected by Satpathy and Reddy (2013) for Cu:- 80 to 210 and Zn:- 60 to 180 at 45 days of harvest. The translocation index value (\%) for $\mathrm{Zn}$ was more than for $\mathrm{Cu}$. This was in line with the report of Ghafoori et al. (2011) who studied and observed that plant with high translocation index for a certain metal would be able to tolerate and accumulate high concentrations of such metals in the shoot, and thus could be considered potential bio-accumulator species of such metal. Amaranthus viridis translocated more of $\mathrm{Zn}$ than $\mathrm{Cu}$. This could be traced to the antagonistic reaction between $\mathrm{Zn}$ and $\mathrm{Cu}$ (Kabata-Pendias and Pendias, 1992). Reduction in $\mathrm{Cu}$ availability resulted from its complex formation with organic matter in soil amended with sludge and became less mobile (Zhu and Alva, 1993). However, translocation index values lower than 100 indicated that more heavy metals concentration was in the root than in the shoot. The values of translocation index for $\mathrm{Cu}$ in the sludge amendments were not significantly $(p>0.05)$ 
different but highly significant $(\mathrm{p}<0.05)$ for $\mathrm{Zn}$. Oke-afa sludge and $67.5 \mathrm{~kg}$ Abesan sludge The values of translocation index for $\mathrm{Cu}$ and $\mathrm{Zn}$ were highest in the soil pots amended with $67.5 \mathrm{~kg}$ respectively.

Table 3: Amaranthus viridis bioconcentration factor

\begin{tabular}{lll}
\hline $\left.\begin{array}{l}\text { Amended Quantity } \\
(\mathrm{kg} \mathrm{N} \mathrm{ha}\end{array}{ }^{-1}\right)$ & $\mathrm{Cu}$ & $\mathrm{Zn}$ \\
\hline 67.5 SSA & $0.71 \pm 0.17^{\mathrm{ab}}$ & $43.43 \pm 1.43^{\mathrm{bc}}$ \\
87.5 SSA & $0.72 \pm 0.06^{\mathrm{ab}}$ & $17.22 \pm 0.11^{\mathrm{a}}$ \\
107.5 SSA & $0.52 \pm 0.15^{\mathrm{a}}$ & $56.89 \pm 5.43^{\mathrm{de}}$ \\
67.5 SSI & $0.97 \pm 0.15^{\mathrm{b}}$ & $52.51 \pm 2.58^{\mathrm{cd}}$ \\
87.5 SSI & $1.50 \pm 0.31^{\mathrm{cd}}$ & $82.03 \pm 9.10^{\mathrm{f}}$ \\
$107.5 \mathrm{SSI}$ & $0.93 \pm 0.22^{\mathrm{b}}$ & $83.89 \pm 10.57^{\mathrm{f}}$ \\
67.5 SSO & $1.79 \pm 0.23^{\mathrm{d}}$ & $82.82 \pm 8.12^{\mathrm{f}}$ \\
87.5 SSO & $0.88 \pm 0.11^{\mathrm{b}}$ & $67.05 \pm 14.94^{\mathrm{e}}$ \\
107.5 SSO & $0.92 \pm 0.19^{\mathrm{b}}$ & $39.44 \pm 2.18^{\mathrm{b}}$ \\
67.5 NPK & $0.67 \pm 0.10^{\mathrm{a}}$ & $54.72 \pm 03.49^{\mathrm{cde}}$ \\
Control & $0.73 \pm 0.08^{\mathrm{ab}}$ & $61.48 \pm 4.20^{\mathrm{de}}$ \\
67.5 Pupuk & $1.34 \pm 0.20^{\mathrm{c}}$ & $80.90 \pm 9.22^{\mathrm{f}}$ \\
\hline
\end{tabular}

Superscripts with the same letters down the column are not significantly $(\mathrm{p}<0.05)$ different. $\mathrm{SS}=$ Sewage Sludge, $\mathrm{SSA}=$ Abesan, SSI = Ikeja, $\mathrm{SSO}=$ Oke-afa

Effects of sewage sludge amendments on soil heavy metal availability

Analysing the amended soil after $A$. viridis was harvested, it was found that availability of $\mathrm{Cr}$ and $\mathrm{Pb}$ was higher than before planting (Table 5). Levels of $\mathrm{Zn}$ and $\mathrm{Cu}$ in the soil reduced after amended with sludge and harvested Amaranthus viridis. The same was observed by Antonious and Snyder (2007) when they amended native soil with sludge. The reduction in levels of metals could be as a result of organic carbon contents of the sludge. This corroborated the assertion of Bada et al. (2014) that soil organic carbon reduces availability of heavy metal for plant uptake. Availability of the selected heavy metals followed a decreasing order:- $\mathrm{Zn}>\mathrm{Cr}>\mathrm{Pb}$ which corroborated Olayinka et al. (2011) study. The pots amended with $107.5 \mathrm{~kg}$ Abesan sludge, $107.5 \mathrm{~kg}$ Ikeja sludge and $107.5 \mathrm{~kg}$ Oke-afa sludge respectively had the highest $(\mathrm{p}<0.05)$ concentrations of $\mathrm{Cu}, \mathrm{Zn}$ and $\mathrm{Cr}$ after harvest. This showed that it is beneficial to adhere to plant's nitrogen-requirements because high accumulation of heavy metals by plants may pose health risks in men when consumed (Ololade, 2009). The plants germinated faster in the soil amended with sludge than in the soil amended with both NPK and the imported organic fertilizer (Pupuk). This showed the beneficial contributions of the sludge amendments by supporting the test plant for its fast growth rate (Mepha et al., 2007). 
Table 4: Amaranthus viridis translocation index

\begin{tabular}{lll}
\hline $\left.\begin{array}{l}\text { Amended Quantity } \\
(\mathrm{kg} \mathrm{N} \mathrm{ha}\end{array}\right)$ & $\mathrm{Cu}$ & $\mathrm{Zn}$ \\
\hline 67.5 SSA & $52.51 \pm 5.92^{\mathrm{ab}}$ & $70.17 \pm 1.00^{\mathrm{f}}$ \\
87.5 SSA & $46.30 \pm 6.42^{\mathrm{ab}}$ & $68.73 \pm 1.79^{\mathrm{f}}$ \\
$107.5 \mathrm{SSA}$ & $49.50 \pm 5.21^{\mathrm{ab}}$ & $56.77 \pm 3.15^{\mathrm{b}}$ \\
$67.5 \mathrm{SSI}$ & $54.47 \pm 7.74^{\mathrm{ab}}$ & $69.58 \pm 1.13^{\mathrm{f}}$ \\
87.5 SSI & $45.83 \pm 7.22^{\mathrm{ab}}$ & $61.85 \pm 1.13^{\mathrm{cd}}$ \\
$107.5 \mathrm{SSI}$ & $45.37 \pm 4.12^{\mathrm{ab}}$ & $46.84 \pm 3.44^{\mathrm{a}}$ \\
$67.5 \mathrm{SSO}$ & $56.37 \pm 4.18^{\mathrm{b}}$ & $62.38 \pm 0.46^{\mathrm{cd}}$ \\
87.5 SSO & $47.46 \pm 4.26^{\mathrm{ab}}$ & $59.81 \pm 1.21^{\mathrm{bc}}$ \\
$107.5 \mathrm{SSO}$ & $48.04 \pm 4.58^{\mathrm{ab}}$ & $66.64 \pm 1.86^{\mathrm{ef}}$ \\
$67.5 \mathrm{NPK}$ & $48.42 \pm 9.00^{\mathrm{ab}}$ & $64.93 \pm 1.55^{\mathrm{de}}$ \\
Control & $47.61 \pm 2.51^{\mathrm{ab}}$ & $61.42 \pm 2.90^{\mathrm{cd}}$ \\
67.5 Pupuk & $43.77 \pm 3.56^{\mathrm{a}}$ & $59.85 \pm 2.09^{\mathrm{bc}}$ \\
\hline
\end{tabular}

Superscripts with the same letters down the column are not significantly $(\mathrm{p}<0.05)$ different. SS = Sewage Sludge, SSA = Abesan, SSI = Ikeja, SSO = Oke-afa

Table 5: Effects of sewage sludge amendments on soil heavy metal availability

\begin{tabular}{llllll}
\hline $\begin{array}{l}\text { Amended } \\
\text { Quantity }\left(\mathrm{kg} \mathrm{N} \mathrm{ha}^{-1}\right)\end{array}$ & $\mathrm{Cu}$ & $\mathrm{Zn}$ & $\begin{array}{l}\mathrm{Cr} \\
\left(\mathrm{mg} \mathrm{kg}^{-1}\right)\end{array}$ & $\mathrm{Cd}$ & $\mathrm{Pb}$ \\
\hline 67.5 SSA & $0.76 \pm 0.04^{\mathrm{d}}$ & $3.80 \pm 0.09^{\mathrm{e}}$ & $1.25 \pm 0.05^{\mathrm{cd}}$ & $<\mathrm{DL}$ & $0.96 \pm 0.08^{\mathrm{b}}$ \\
87.5 SSA & $0.74 \pm 0.04^{\mathrm{d}}$ & $3.78 \pm 0.03^{\mathrm{e}}$ & $1.29 \pm 0.09^{\mathrm{d}}$ & $<\mathrm{DL}$ & $<\mathrm{DL}$ \\
107.5 SSA & $1.03 \pm 0.09^{\mathrm{e}}$ & $2.70 \pm 0.08^{\mathrm{bc}}$ & $1.62 \pm 0.11^{\mathrm{e}}$ & $<\mathrm{DL}$ & $<\mathrm{DL}$ \\
67.5 SSI & $0.52 \pm 0.01^{\mathrm{b}}$ & $2.86 \pm 0.06^{\mathrm{bcd}}$ & $1.24 \pm 0.04^{\mathrm{cd}}$ & $<\mathrm{DL}$ & $<\mathrm{DL}$ \\
87.5 SSI & $0.33 \pm 0.03^{\mathrm{a}}$ & $2.18 \pm 0.29^{\mathrm{a}}$ & $1.17 \pm 0.06^{\mathrm{bc}}$ & $<\mathrm{DL}$ & $<\mathrm{DL}$ \\
107.5 SSI & $0.63 \pm 0.04^{\mathrm{c}}$ & $4.06 \pm 0.06^{\mathrm{e}}$ & $1.17 \pm 0.09^{\mathrm{bc}}$ & $<\mathrm{DL}$ & $<\mathrm{DL}$ \\
67.5 SSO & $0.30 \pm 0.03^{\mathrm{a}}$ & $2.25 \pm 0.03^{\mathrm{a}}$ & $1.26 \pm 0.04^{\mathrm{cd}}$ & $<\mathrm{DL}$ & $<\mathrm{DL}$ \\
87.5 SSO & $0.61 \pm 0.05^{\mathrm{c}}$ & $3.10 \pm 0.63^{\mathrm{cd}}$ & $1.00 \pm 0.025^{\mathrm{a}}$ & $<\mathrm{DL}$ & $0.525 \pm 0.090^{\mathrm{a}}$ \\
107.5 SSO & $0.63 \pm 0.04^{\mathrm{c}}$ & $3.98 \pm 0.09^{\mathrm{e}}$ & $3.81 \pm 0.06^{\mathrm{f}}$ & $<\mathrm{DL}$ & $<\mathrm{DL}$ \\
67.5 NPK & $0.79 \pm 0.04^{\mathrm{d}}$ & $3.14 \pm 0.10^{\mathrm{d}}$ & $1.00 \pm 0.03^{\mathrm{a}}$ & $<\mathrm{DL}$ & $<\mathrm{DL}$ \\
Control & $0.73 \pm 0.03^{\mathrm{d}}$ & $2.96 \pm 0.08^{\mathrm{cd}}$ & $1.24 \pm 0.04^{\mathrm{cd}}$ & $<\mathrm{DL}$ & $<\mathrm{DL}$ \\
67.5 Pupuk & $0.46 \pm 0.04^{\mathrm{b}}$ & $2.50 \pm 0.13^{\mathrm{ab}}$ & $1.07 \pm 0.063^{\mathrm{ab}}$ & $<\mathrm{DL}$ & $<\mathrm{DL}$ \\
\hline
\end{tabular}

Superscripts with the same letters down the column are not significantly $(\mathrm{p}<0.05)$ different. $\mathrm{SS}=$ Sewage Sludge, $\mathrm{SSA}=$ Abesan, $\mathrm{SSI}=\mathrm{Ikeja}, \mathrm{SSO}=$ Oke-afa

\section{O N C L U S I O N RECOMMENDATIONS}

Levels of heavy metals in both soil and sewage sludge samples were low and this made the sludge suitable. Level of absorbed heavy metals in the plants was lower than in the soil after harvest as the transfer factor was lower than 1, except for $\mathrm{Zn}$ concentration and bioconcentration factor was lower than 100. Levels of heavy metals were more in the root than in the shoot because the translocation index value was lower than 100 . Both $\mathrm{Cd}$ and $\mathrm{Pb}$ which are toxic metals of great concern to human health were not detected in the plants from the indices computed.

Having found that the levels of heavy metals in the test plant were lower than available in the soil after harvest, the study concluded that sludge may be sustainably beneficial for soil amendment and land application as alternative means to sludge disposal.

\section{ACKNOWLEDGEMENTS}

We are pleased to say a big thanks to the Lagos 
State Government through the WasteWater Management Office, Obasa, Ikeja, Nigeria for giving us the valuable assistance to reach its three functional outlets to collect the sewage sludge (SS) samples for our research purposes. Thanks to Rooreromi Qanita and Olaide Khadijat for the typesetting and proof reading.

\section{REFERENCES}

Abe, T., Fukami, M., Ichizen, N. and Ogasawara, M. 2006. Susceptibility of weed species to cadmium evaluated in a sand culture. Weed Biolog. Manage 6(2): 107-114.

Antonious, G. F. 2003. Impact of Soil Management and Two Botanical Insecticides on Urease and Invertase Activity. Journal of Environmental Science and Health, Part B. 38: 479-488.

Antonious, G. F. and Snyder, J. C. 2007. Accumulation of Heavy Metals in Plants and Potential Phytoremediation of Lead by Potato, Solanum tuberosum L. Journal of Environmental Science and Health Part A, 42: 811-816.

Antonious, G. F., Dennis, S. O., Unrine, J. M. and Snyder, J. C. 2011. Heavy Metals Uptake in Plant Parts of Sweetpotato Grown in Soil Fertilized with Municipal Sewage Sludge. International Journal of Geology 5(1): 14-20.

Bada, B. S., Arowolo, T. A. and Ozoike, P. N., 2014. Assessment of Heavy Metal Content of Soil and Kenaf (Hibiscus cannabinus Linn.) in a Nutrient Degraded Soil Amended with Dairy Sludge. Journal of Applied Phytotechnology in Environmental Sanitation 3(4): 137-145.

Ghafoori, M., Nik, M. M., Islam, M. M. and Sylvia, L., 2011. Bioaccumulation of Heavy Metals by Dyera Costulata Cultivated in Sewage Sludge Contaminated Soil. African Journal of Biotechnology 10(52): 1067410682.

Gupta, N., Khan, D. K. and Santra, S. C. 2008. An Assessment of Heavy Metal Contamination in Vegetables Grown in Wastewater-irrigated Areas of Titagarh, West Bengal, India. B. Environ. Contam. Tox. 80(2): 115-118.

Kabata-Pendias, A. and Pendias, H. 1992. Trace Elements in Soil and Plants. CRC Pres. Boca Raton, Florida, pp. 365.
Kabata-Pendias, A. and Pendias, H., 1999. Biogeochemistry of Trace Elements. Ed Scientific, PWN, Warsaw (in Polish).

Kamran, S., Shafaqat, A., Samra, H., Sana, A., Samar, F., Muhammad, B. S., Saima, A. B. and Hafiz, M. T. 2013. Heavy Metals Contamination and what are the Impacts on Living Organisms. Greener J. of Environmental Management and Public Safety 2 (4): 172-179.

Khalid, U., Sarfaraz, K., Said, G., Muhammad, U. K., Niamatullah, K., Muhammad, A. K. and Shad, K. K., 2012. Sewage Sludge: An Important Biological Resource for Sustainable Agriculture and Its Environmental Implications. American Journal of Plant Sciences 3: 1708-1721.

Kumar, S., Bhattacharyya, J. K., Vaidya, A. N., Chakrabarti, T., Devotta, S. and Akolkar, A. B. 2009. Assessment of the Status of Municipal Solid Waste Management in Metro Cities, State Capitals, Class I Cities and Class II Towns in India: An insight. Waste Manag. 29(2): 883-895.

Mepha, H. D., Eboh, L., and Banigbo, D. E. B., 2007. Effects of Processing Treatments on the Nutritive Composition and Consumer Acceptance of some Nigerian Edible Leafy Vegetables. African Journal of Food, Agriculture and Nutrition Development 7(1):1-18.

Mishra, V. K., Upadhyaya, A. R., Pandey, S. K. and Tripathi, B. D. 2008. Heavy metal Pollution Induced due to Coal Mining Effluent on Surrounding Aquatic Ecosystem and its Management through Naturally Occurring Aquatic Macrophytes. Bioresour. Technol. 99(5): 930936.

Nurunnahar, S., Joardar, J. C., Shamima, N., Rashid, M. H. and Imamul Huq, S. M.., 2012. Response of Broccoli to Organic Amendments and Accumulation of Heavy Metals in it. Bangladeshi Journals of Science Resources 25 (1): 1-10.

Olayinka, K. O., Oyeyiola, A. O., Odujebe, F. O. and Oboh, B., 2011. Uptake of Potentially Toxic Metals by Vegetable Plants grown on Contaminated Soil and their Potential Bioavailability using Sequential Extraction; Journal of Soil Science and 
EnvironmentalManagement 2(8): 220-227.

Ololade, I. A., 2009. Prediction of Extractable Metals $(\mathrm{Cd}, \mathrm{Pb}, \mathrm{Fe} \mathrm{Cu}, \mathrm{Mn}$ and $\mathrm{Zn})$ in Sewage. African Journal of Agricultural Research 4(11): 1234-1240.

Oros, V., 2001. Heavy Metals Biomonitoring, (in Romanian), North University Baia Mare, Romania.

Priya, V. P., Celine, V. A., Gokulapalan, C. and Rajamony, L. 2007. Screening Amaranth Genotypes (Amaranthus spp.) for Yield and Resistance to Leaf Blight Caused by Rhizoctonia Solani Kuhn. Plant Genet Res Newsletter. 147: 1-4.

Satpathy, D. and Reddy, M. V. 2013. Phytoextraction of $\mathrm{Cd}, \mathrm{Pb}, \mathrm{Zn}, \mathrm{Cu}$ and Mn by Indian Mustard (Brassica juncea L.) Grown on Loamy Soil Amended with Heavy metal Contaminated Municipal Solid Waste Compost. Applied Ecology and EnvironmentalResearch 11(4): 661-679.

Usma, M. Sarfaaz, Z., Maqsood, A., Ashraf, K.,
Adnan, M. and Iqbal, A. 2013. A Review: Phytoextraction, an Effective Application to Remove Pollution and Heavy Metals from Water. International Journal of Water Resources and Environmental Sciences 2(3): 6065.

Wang, P. F., Zhang, S. H., Wang, C., Hou, J., Guo, P. C. and Lin, Z. P. 2008. Study of heavy metal in sewage sludge and in Chinese cabbage grown in soil amended with sewage sludge. African Journal of Biotechnology 7 (9): 1329-1334.

Yadav, A., Yadav, P. K. and Shukla, D. N. 2013. Investigation of Heavy Metal Status in Soil and Vegetables Grown in Urban Areas of Allahabad, Utlar Pradesh, India. International Journal of Scientific and Research Publication 3(9): 1-7.

Zhu, B. and Alva, A. K. 1993. Differential Adsorption of Trace Metals by Soils as Influenced by Exchangeable Cations and Ionic Strength. Soil Sci. 155: 61-66. 